\title{
MANAJEMEN PENGATURAN RUANG PENYIMPANAN DINGIN DAN KELUHAN COLD STRESS PADA PERUSAHAAN ES KRIM SURABAYA TAHUN 2017
}

\author{
Feby Indah Kurnia, Hadi Suryono, Koerniasari
}

\begin{abstract}
ABSTRAK
Cold Storage merupakan suatu ruang pendingin yang menampung bendabenda yang akan mengalami proses pendinginan. Cold storage Salah Satu Perusahaan Es Krim di Surabaya memiliki suhu $-26^{\circ} \mathrm{C}$ sampai dengan $-20^{\circ} \mathrm{C}$. Paparan suhu dingin pada karyawan dapat menyebabkan penyakit akibat kerja seperti chillblain, immersion foot, trench foot, frostnip, frostbite, hipotermia. Tujuan penelitian ini adalah mengetahui manajemen ruang penyimpanan dingin (cold storage) dan keluhan cold stress.

Penelitian merupakan penelitian deskriptif dengan subyek penelitian yaitu populasi tenaga kerja di ruang cold storage sebanyak 45 orang dan obyek penelitian manajemen ruang cold storage dan keluhan karyawan. Sampel yang diambil sebanyak 40 yang terdiri dari karyawan dengan teknik pengambilan sampel secara acak sederhana (simple random sampling). Instrumen penelitian yang digunakan adalah kuesioner checklist, wawancara dan pengukuran.

Hasil penelitian yang telah diperoleh yaitu beberapa faktor pemaparan suhu dingin pada salah satu perusahaan es krim di Surabaya antara lain: (1)Fungsi Manajemen meliputi penerapan fungsi perencanaan $75 \%$, pengorganisasian $75 \%$, pelaksanaan $100 \%$, dan pengawasan $80 \%$ (2)Keluhan Cold Stress yang meliputi beberapa keluhan yaitu: Menggigil 20,5\%, Hidung Berair 17\%, Mati rasa 25,9\%, Otot Kaku 22,3\%, dan Keluhan lain 9,8\%. (3)Pengendalian Paparan Suhu Dingin yang diterapkan pengendalian teknis $72,2 \%$, administrasi $60 \%$, Alat Pelindung Diri (APD) $92 \%$.

Secara umum dapat disimpulkan manajemen pengaturan ruang penyimpanan dingin $81 \%$ dikategorikan baik, keluhan yang dialami responden keluhan sedang sebanyak 2-3 keluhan sebesar $61,4 \%$, pengendalian yang diterapkan $81,2 \%$ dikategorikan baik. Berdasarkan kekurangan yang ada perlu adanya penyediaan sepatu boots bagi karyawan bagian lain, pelatihan bagi karyawan, dan ruang penghangat tubuh.

Kata Kunci : Manajemen Ruang Cold Storage, Keluhan Cold stress, Pengendalian Paparan Suhu Dingin
\end{abstract}

\section{PENDAHULUAN}

Pengertian lingkungan kerja merupakan tempat atau suatu lingkungan yang digunakan oleh para tenaga kerja untuk menyelesaikan tugas dan tanggung jawab yang telah diberikan kepada tenaga kerja tersebut. Lingkungan kerja sendiri berpengaruh terhadap tingkat produktivitas tenaga kerjanya, semakin lingkungan kerja tersebut nyaman maka tenaga kerja akan semakin produktif dalam menyelesaikan tugas yang telah diberikan.

Menurut UU No. 1 Tahun 1970, kecelakaan kerja adalah suatu kejadian yang tidak dikehendaki dan tidak diduga semula yang dapat menimbulkan korban manusia dan atau harta benda. Kecelakaan kerja dapat menimbulkan banyak kerugian baik dari perusahaan, alat maupun dari pekerja tersebut seperti perusahaan yang tidak dapat melanjutkan proses produksi akibat kecelakaan kerja tersebut. Kerusakan alat yang ditimbulkan akibat kecelakaan kerja dapat mempengaruhi proses produksi di industri tersebut, sedangkan kecelakaan yang terjadi oleh pekerja tersebut akan mengakibatkan pekerja kehilangan waktu kerja serta kerugian fisik maupun ekonomi serta psikis yang dialami oleh keluarga dan pekerja tersebut akibat kecelakaan kerja yang terjadi. Menurut Permenakertrans No. 1 Tahun 1981, Penyakit akibat kerja adalah setiap penyakit yang disebabkan oleh pekerjaan atau lingkungan kerja.

Setiap pekerjaan merupakan beban bagi pelakunya. Beban kerja yang 
merupakan beban langsung akibat pekerjaan atau beban pekerjaan yang sebenarnya, pekerjaan biasanya dilakukan dalam suatu lingkungan atau situasi, yang menyebabkan adanya beban tambahan kepada tenaga kerja baik jasmaniah maupun rohaniah, Terdapat 5 (lima) faktor penyebab beban tambahan dimaksud adalah Faktor fisik (suara, radiasi, suhu yang terlalu tinggi maupun suhu yang terlalu rendah, tekanan udara, penerangan lampu), Faktor kimiawi (debu, uap, gas, larutan zat kimia, awan atau kabut), Faktor biologis (bibit penyakit), Faktor fisiologis/ergonomis (kesalahan konstruksi mesin, sikap badan yang tidak benar dalam melakukan pekerjaan), Faktor mental-psikologis yaitu reaksi mental dan kejiwaan terhadap suasana kerja, hubungan antara pengusaha dan tenaga kerjanya, struktur dan prosedur organisasi pelaksanaan kerja dan lain-lain (Suma'mur, 2009).

Salah satunya faktor fisik adalah suhu rendah (suhu dibawah suhu nyaman $<18^{\circ} \mathrm{C}$ ) yang dapat menimbulkan berbagai masalah kesehatan pada tenaga kerjanya. Tempat yang bersuhu rendah ditemukan di industri makanan yang dikemas dan dibekukan atau industri pembekuan antara lain untuk : es krim, daging, udang, ikan dan sebagainya. Lingkungan tempat kerja dingin (bersuhu rendah); maksudnya suhu udara lingkungan tempat kerja tersebut di bawah normal (suhu kamar) sesuai dengan Kepmenkes No 1405 tahun 2002 yang menyebutkan bahwa dilingkungan perkantoran dan industri persyaratan suhu berkisar antara $18-28^{\circ} \mathrm{C}$, hal demikian telah menyebabkan cuaca atau iklim di dalam lingkungan tersebut berubah dan mengakibatkan terjadinya tekanan dingin (cold stress) yang akan diterima oleh tenaga kerja yang bekerja di lingkungan tersebut.

Tekanan dingin (cold stress) adalah suatu masalah yang sangat berbeda dengan dengan tekanan panas (heat stress), mengingat suhu kulit (suhu tubuh) lebih tinggi dari pada suhu udara lingkungan tempat kerja, maka panas dari tubuh akan dipancarkan dari dalam tubuh ke lingkungan (Utama, 2008). Terdapat berbagai respon fisiologi yang dapat timbul apabila seseorang terpapar dingin adalah suhu kulit menurun, aliran darah kekulit berkurang (penyempitan pembuluh darah kulit), suhu rektal akan sedikit meningkat, menggigil (Siswanto, 1992). Tenaga kerja yang bekerja dilingkungan tempat kerja dingin, umumnya akan kehilangan panas tubuh secara konveksi melalui permukaan tubuh yang terbuka (kaki, tangan, dan lainlain)(Utama, 2008).

Paparan suhu rendah di bawah standar kenyamanan akan menyebabkan perubahan fisiologis dalam tubuh yang akan mengarah pada penyakit akibat kerja seperti Chilblain, Immersion foot, Trench foot, Frostnip, Frostbite, Hipotermia (Harrianto, 2009). Suhu dingin di tempat kerja dapat dipantau setiap waktu dengan menggunakan termometer ruangan yang diletakkan di setiap ruangan. Pada industri makanan terdapat cold storage yang berguna untuk menyi mpan bahan baku atau hasil produksi yang berfungsi untuk memperpanjang umur barang tersebut sehingga tidak cepat mengalami pembusukan.

Salah Satu Perusahaan Es Krim di Surabaya dari hasil survei yang dilakukan, memiliki karyawan sebanyak 500 karyawan yang terbagi dari berbagai bidang (Proses produksi, Penyimpanan dingin, Pencampuran, Penyimpanan produk, Penyimpanan box, Kantor manajemen gudang, Penyimpanan kering, Bengkel, freezing room, laboratorium Quality Control, Quality System), dll) salah satunya terdapat ruangan cold storage yang berguna untuk menyimpan hasil produk es krim yang nantinya akan di distribusikan di berbagai kota di Indonesia.

Salah Satu Perusahaan Es Krim di Surabaya memiliki 3 ruangan anteroom sebelum menuju ke ruangan cold storage atau penyimpanan hasil produksi tersebut. Sedangkan di dalam ruangan cold storage yang terdapat di Perusahaan Es Krim tersebut memiliki suhu $-26^{\circ} \mathrm{C}$ sampai dengan $-20^{\circ} \mathrm{C}$. Tenaga kerja di ruang cold storage terbagi menjadi 3 shift yaitu pagi (08.00- 16.00), siang (16.00-24.00) dan malam (24.00-08.00). Karyawan di ruangan penyimpanan dingin (cold storage) tersebut dilengkapi dengan APD seperti penutup kepala, masker, pakaian 
kerja, sarung tangan, sepatu kerja, mantel pelindung karyawan. Karyawan di ruangan penyimpanan dingin (cold storage), hanya terdapat karyawan pria yang tugasnya melakukan pekerjaan seperti pemindahan barang hasil produksi, melakukan bongkar muat hasil produksi. Keluhan yang dirasakan oleh karyawan adalah sebagian karyawan mengeluh hidungnya berair dan menggigil.

Berdasarkan masalah diatas peneliti tertarik untuk melakukan penelitian yaitu pengaruh dari manajemen ruang seperti proses penyimpanan produk, pengaturan iklim kerja yang meliputi suhu, kelembaban, kecepatan aliran udara dan manajemen karyawan yang meliputi karakteristik karyawan, pemeriksaan kesehatan, asupan makanan, pemakaian Alat Pelindung Diri (APD) tersebut serta keluhan cold stress yang dirasakan pekerja di ruangan cold storage di Salah Satu Perusahaan Es Krim di Surabaya.

\section{METODE PENELITIAN}

Penelitian ini merupakan penelitian deskriptif dan sifatnya penelitian ini merupakan cross sectional dimana variabel sebab akibat atau kasus pada objek penelitian diukur atau dikumpulkan secara simultan. Penelitian dilakukan di salah satu perusahaan es krim di
Surabaya pada bagian Cold Storage. Subyek dalam penelitian adalah populasi yang terdiri dari karyawan ruang cold storage sebanyak 45 orang kemudian diambil sampel menggunakan rumus slovin. Sampel yang diambil di ruang cold storage sebanyak 40 orang terdiri dari karyawan Salah Satu Perusahaan Es Krim di Surabaya. Sampel tersebut menggunakan teknik pengambilan sampel secara acak sederhana (Simple Random Sampling) dengan mengundi anggota populasi setiap shift pada pengelola dan karyawan di ruang cold storage. Obyek penelitian ini adalah penerapan manajemen pengelolaan ruang penyimpanan dingin (cold storage), karakteristik karyawan, dan iklim kerja.

\section{HASIL DAN PEMBAHASAN Manajemen Ruang Penyimpanan Dingin (Cold Storage)}

Dari hasil observasi dan wawancara yang dilakukan kepada 4 orang pengelola mengenai manajemen ruang penyimpanan dingin (Cold Storage) yang meliputi perencanaan, pengorganisasian, pelaksanaan, dan pengawasan di salah satu perusahaan es krim di Surabaya di dapatkan hasil presentase sebesar:

TABEL 1

DISTRIBUSI PENERAPAN FUNGSI MANAJEMEN RUANG

PENYIMPANAN DINGIN (COLD STORAGE) DI SALAH SATU PERUSAHAAN ES KRIM DI SURABAYA TAHUN 2017

\begin{tabular}{llcccccc}
\hline NO & $\begin{array}{c}\text { FUNGSI } \\
\text { MANAJEMEN }\end{array}$ & $\begin{array}{c}\text { JUMLAH } \\
\text { PERTANYAAN }\end{array}$ & DITERAPKAN & $\%$ & $\begin{array}{c}\text { TIDAK } \\
\text { DITERAPKAN }\end{array}$ & $\%$ \\
\hline 1 & Fungsi Perencanaan & 16 & 100 & 10 & 75 & 4 & 28,6 \\
\hline 2 & $\begin{array}{l}\text { Fungsi } \\
\text { Pengorganisasian }\end{array}$ & 4 & 100 & 3 & 75 & 1 & 25 \\
\hline 3 & Fungsi Pelaksanaan & 7 & 100 & 7 & 100 & 0 & 0 \\
\hline 4 & Fungsi Pengawasan & 10 & 100 & 8 & 80 & 2 & 20 \\
\hline & Jumlah & 37 & 100 & 30 & 81 & 7 & 19 \\
\hline
\end{tabular}

Berdasarkan kriteria tersebut didapatkan hasil penerapan manajemen sebagai berikut:

Fungsi Perencanaan
1. Terdapat
rencana
program

pengendalian yang dilakukan perusahaan untuk mencegah terjadi kecelakaan.

2. Tersedia jumlah dan kualitas APD sudah memenuhi persyaratan 
3. Dilakukan penjadwalan untuk pergantian/perawatan APD

4. Perusahaan menyediakan anggaran yang cukup untuk penyedian APD

5. Diadakan pemeriksaan sebelum bekerja bagi tenaga kerja

6. Diadakan pemeriksaan berkala bagi tenaga kerja

7. Perusahaan menyediakan anggaran pegawainya pada program asuransi kesehatan

8. Terdapat layout/ desain perencenaan ruang cold storage

9. Terdapat program Keselamatan dan Kesehatan Kerja (K3) di perusahaan

10. Kapasitas ruang cold storage sesuai dengan hasil produksi

11. Terdapat perencanaan perawatan mesin yang digunakan di ruang cold storage

12. Terdapat mekanisme yang dilakukan perusahaan untuk mengawasi kehadiran tenaga kerja (Checklock, tanda tangan)

Fungsi Pengorganisasian

1. Terdapat struktur organisasi pengelolaan ruang cold storage

2. Terdapat pembagian tugas pokok dan fungsi pada ruang cold storage

3. Dilakukannya pendelegasian wewenang pada departemen cold storage

Fungsi Pelaksanaan

1. Terdapat peraturan yang mengatur penggunaan APD dan telah diterapkan oleh tenaga kerja

2. Tersedia SOP yang diterapkan dalam pengelolaan ruang cold storage

3. Dilakukan tindak lanjut terhadap keluhan yang dilaporkan
4. Dilakukan pengukuran suhu dingin dalam rangka pengaturan suhu ruangan

5. Dilaksanakan proggram K3 (Terdapat peraturan penggunaan APD, Jadwal kerja, pelatihan tanggap darurat, dan tersedia APAR)

6. Dilaakukan perawatan mesin

7. Dilakukan perawatan APD

\section{Fungsi Pengawasan}

1. Dilakukan pengawasan penggunaan APD bagi tenaga kerja

2. Perusahaan memiliki laporan angka kecelakaan dan kesakitan tenaga kerja

3. Dilakukan evaluasi kinerja di ruang cold storage secara rutin

4. Dilakukan pengawasan pengaturan suhu ruang cold storage

Berdasarkan penerapan manajemen yang tidak diterapkan sebagai berikut:

Fungsi Perencanaan

1. Tidak diadakan pemeriksaan khusus bagi tenaga kerja

2. Tidak terdapat tenaga medis pada klinik perusahaan

3. Tidak terdapat kriteria persyaratan tenaga kerja

4. Tidak terdapat perencanaan pengaturan suhu ruangan

Fungsi Pengorganisasian

1. Tidak dilakukan penggantian tenaga kerja yang memiliki masa kerja cukup lama (misalnya dipindahkan ke bagian lain)

\section{Fungsi Pengawasan}

1. Tidak terdapat laporan keluhan tenaga kerja 


\section{Keluhan Karyawan}

Dari penelitian yang dilakukan terhadap 40 responden diperoleh hasil sebagai berikut:

TABEL 2

JUMLAH KELUHAN YANG DIALAMI RESPONDEN DI SALAH SATU PERUSAHAAN ES KRIM DI SURABAYA TAHUN 2017

\begin{tabular}{lllll}
\hline \multirow{2}{*}{ NO. } & $\begin{array}{c}\text { JUMLAH } \\
\text { KELUHAN }\end{array}$ & $\begin{array}{c}\text { JUMLAH } \\
\text { RESPONDEN }\end{array}$ & \multicolumn{1}{c}{ KRITERIA } & \multicolumn{1}{c}{ PRESENTASE } \\
\hline 1. & 4 Keluhan & 8 orang & Berat & 18,2 \\
\hline 2. & 2-3 Keluhan & 27 orang & Sedang & 61,4 \\
\hline 3. & 1 Keluhan & 4 Orang & Ringan & 9 \\
\hline & Tidak ada & & Tidak Ada & 11,4 \\
\hline 4. & Keluhan & 5 Orang & Keluhan & \\
\hline & Jumlah & 44 Orang & & 100 \\
\hline
\end{tabular}

\section{Pengendalian Pengaruh Suhu Dingin}

Dari hasil observasi dan wawancara yang dilakukan mengenai pengendalian yang meliputi pengendalian teknis, administrasi, Alat Pelindung Diri (APD) ruang penyimpanan dingin (Cold Storage) di salah satu perusahaan es krim di Surabaya maka didapatkan hasil sebagai berikut :

TABEL 3

PENGENDALIAN PADA RUANG PENYIMPANAN DINGIN (COLD STORAGE) DI SALAH SATU PERUSAHAAN ES KRIM DI SURABAYA TAHUN 2017

\begin{tabular}{llcccccc}
\hline NO & $\begin{array}{c}\text { FUNGSI } \\
\text { MANAJEMEN }\end{array}$ & $\begin{array}{c}\text { JUMLAH } \\
\text { PERTANYAAN }\end{array}$ & $\%$ & DITERAPKAN & $\%$ & $\begin{array}{c}\text { TIDAK } \\
\text { DITERAPKAN }\end{array}$ & $\%$ \\
\hline 1 & Pengendalian teknis & 18 & 100 & 17 & 72,2 & 5 & 27,8 \\
\hline 2 & $\begin{array}{l}\text { Pengendalian } \\
\text { administrasi }\end{array}$ & 5 & 100 & 3 & 60 & 2 & 40 \\
\hline 3 & Pengendalian APD & 25 & 100 & 23 & 92 & 2 & 8 \\
\hline & Jumlah & 48 & 100 & 39 & 81,2 & 9 & 18,78 \\
\hline
\end{tabular}

Pengukuran pengendalian yang diterapkan disalah satu perusahaan es krim di Surabaya sebagai berikut :

Pengendalian Teknis

1. Konstruksi bangunan terbuat dari bahan yang kuat

2. Bangunan bersih dan terpelihara

3. Lantai terbuat dari bahan yang kuat

4. Lantai kedap air

5. Dinding terbuat dari bahan yang kuat

6. Permukaan dinding rata

7. Dinding berwarna terang

8. Permukaan dinding terbuat dari bahan yang kedap air

9. Kondisi dinding bersih

10. Langit-langit bersih

11. Langit-langit berwarna terang
12. Tinggi langit-langit $\min 2,5 \mathrm{~m}$ dari lantai

13. Konstruksi langit-langit terbuat dari bahan yang kuat

Pengendalian Administrasi

1. Diadakan pelatihan yang dilakukan lebih dari 1 kali

2. Perusahaan memberlakukan shift kerja

3. Perusahaan memberikan asupan makanan kepada tenaga kerja

Pengendalian APD

1. Terdapat ruang penyimpanan APD

2. Kondisi APD penutup kepala utuh, menutup bagian rambut dan telinga, bersih dan kuat

3. Masker utuh, bersih dan kuat 
4. Pakaian kerja utuh, bersih dan kuat

5. Sarung tangan utuh, melindungi tangan dan jari-jari, bersih, kuat

6. Sepatu kerja utuh, melindungi kaki, bersiih, kuat

7. Mantel utuh, melindungi dari terpaan angin, bersih, kuat

Berdasarkan penerapan pengendalian yang tidak diterapkan adalah sebagai berikut:

Pengendalian Teknis

1. Permukaan lantai tidak rata

2. Kondisi lantai licin

3. Lantai tidak bersih

4. Pencahayaan menimbulkan cahaya

Pengendalian Administrasi

1. Tidak terdapat ruangan yang berfungsi untuk menghangatkan tenaga kerja

2. Tidak terdapat tanda bahaya di ruanng cold storage pada alat, bahan, mesin, listrik, dll

3. Tidak terdapat tanda-tanda bahaya terpasang dengan baik sesuai dengan fungsinya

Pengendalian Alat Pelindung Diri (APD)

1. Masker tidak dapat melindungi hisung dan muka

2. Pakaian kerja tidak menutupi seluruh bagian tubuh dan kering

\section{KESIMPULAN}

1. Hasil dari penerapan manajemen ruang penyimpanan dingin pada salah satu perusahaan es krim di Surabaya yang meliputi fungsi perencanaan, pengorganisasian, pelaksanaan, dan pengawasan sebesar $81 \%$ yang dikategorikan baik.

2. Hasil kuesioner wawancara mengenai keluhan yang dialami responden didapatkan hasil sebagai berikut: keluhan berat sebesar 18,2\%, keluhan sedang $61,4 \%$, keluhan ringan $9 \%$, tidak ada keluhan sebesar $11,4 \%$.

3. Hasil pengendalian paparan suhu dingin yang diterapkan oleh salah satu perusahaan es krim di Surabaya sebesar $81,2 \%$ yang dikategorikan baik.

\section{SARAN}

Fungsi Perencanaan

1. Sebaiknya perusahaan memiliki klinik perusahaan dan terdapat tenaga medis, sehingga apabila terjadi kecelakaan atau kesakitan kerja dapat segera mendapat pertolongan pertama.

2. Perusahaan sebaiknya merencanakan rekrutmen untuk tenaga Keselamatan dan Kesehatan Kerja (K3).

3. Perusahaan sebaiknya melakukan penjadwalan secara rutin untuk penggantian Alat Pelindung Diri (APD) sesuai masa pakai APD tersebut pada karyawan ruang penyimpanan dingin (cold storage) sehingga dapat mengurangi keluhan yang dialami oleh karyawan.

\section{Fungsi Pengorganisasian}

1. Perusahaan perlu melakukan penggantian karyawan yang memiliki masa kerja cukup lama ke bagian lain atau ketempat lain yang lebih hangat untuk mengurangi keluhan kesehatan yang dialami oleh karyawan.

\section{Fungsi Pengawasan}

1. Perusahaan sebaiknya mendokumentasikan keluhan yang dialami oleh karyawan ruang penyimpanan dingin (cold storage) untuk keperluan pengawasan kesehatan kerja.

2. Pada ruang penyimpanan dingin (cold storage) sebaiknya disediakan kotak saran untuk menampung keluhan karyawan dan juga sebagai kontrol pengelola mengenai penerapan manajemen ruang penyimpanan dingin (cold storage).

Pengendalian Teknis

1. Pengelola ruang penyimpanan dingin (cold storage) sebaiknya menyediakan sepatu safety/ boots bagi karyawan bagian lain yang akan masuk ke ruangpenyimpanan dingin (cold storage) atau memberi permukaan lantai dengan lapisan karet sehingga mengurangi kecelakaan/terpeleset. 
Pengendalian Administrasi

1. Sebaiknya pengelola ruang penyimpanan dingin (cold storage) memberi tanda bahaya pada alat, mesin, bahan dan listrik untuk mengurangi terjadinya kecelakaan kerja.

2. Sebaiknya pengelola ruang penyimpanan dingin (cold storage) memberikan Alat Pelindung Diri seperti masker yang menutupi hidung dan muka, serta pakaian kerja yang berlengan panjang untuk mengurangi keluhan yang dialami oleh karyawan.

3. Perlu diselenggarakan pelatihan, penyuluhan ataupun pendidikan tentang keselamatan dan kesehatan kerja yang terkait dengan cold stress sehingga karyawan lebih peduli terhadap peraturan yang ditetapkan dan dapat waspada terhadap diri sendiri.

4. Perusahaan seharusnya menyediakan ruang penghangat tubuh bagi karyawan ruang penyimpanan dingin (cold storage) agar pada saat jam istirahat tubuh karyawan dapat pulih sehingga kinerja karyawan semakin meningkat.

\section{DAFTAR PUSTAKA}

Harrianto, Ridwan, 2009. Buku Ajar Kesehatan Kerja. Jakarta, Buku Kedokteran EGC:151- 166.
Keputusan Menteri Kesehatan

$\begin{array}{lrr}\text { Republik } & \text { Indonesia } & \text { Nomor } \\ \text { 1405/MENKE } & \text { S/SK/XI/2 } & 002 \\ \text { Tentang } & \text { Persyaratan } \\ \text { Kesehatan lingkungan } & \text { Kerja } \\ \text { Perkantoran dan Industri } & \end{array}$

Keputusan Presiden No. 22 Tahun 1993 Tentang Penyakit Yang Timbul Karena Hubungan Kerja

Peraturan Menteri Tenaga Kerja dan Transmigrasi Nomor PER.0 1/MEN/1 981 Tentang Kewajiban Melapor Penyakit Akibat Kerja

Peraturan Menteri Tenaga Kerja dan Transmigrasi Republik Indonesia Nomor PER. 13/MEN/X/2011 Tentang Nilai Ambang Batas Faktor Fisika dan Faktor Kimia di Temp at Kerja

Peraturan Menteri Tenaga Kerja dan Transmigrasi Republik Indonesia Nomor PER. 08/MEN/VII/2010 Tentang Alat Pelindung Diri

Suma'mur, 2009. Higiene Perusahaan dan Kesehatan Kerja (HIPERKES). Jakarta, CV Sagung Seto: 74-161

Undang-Undang Republik Indonesia Nomor 1 Tahun 1970 Tentang Keselamatan Kerja Utama, Hendra, 2008. Higiene Industri. Jakarta, Balai Penerbit FKUI: 310-320 